\title{
LAND COVER CHANGE ANALYSIS AROUND THE SUNDARBANS MANGROVE FOREST OF BANGLADESH USING REMOTE SENSING AND GIS APPLICATION
}

\author{
M M Rahman' ${ }^{1}$ and S Begum²
}

\begin{abstract}
Land cover change is a widespread and prominent feature in Bangladesh. It is more energetic in the South-west coastal region such as Khulna and Satkhira region. The research was completed by 30 years (1980 to 2009) by using four Landsat satellite images (1980, 1989, 2002 and 2009). During research it was originated that the main classes of changes were homestead, fallow land, water bodies and mangrove vegetation in the study area. The most imperative change was observed in fallow lands (the types of cultivable lands with or without any standing crops and also uncultivable lands). Fallow land was decreased, concerning 2,259 sq km in 2009 which land was 3,867 sq km during in 1980. It was dropped $49 \%$ to $29 \%$ of total study area between the years of 1980 to 2009 . The water bodies were increased about $10 \%$ in those 30 years, regarding $14 \%$ to $24 \%$. The total water bodies covered 1140 sq km at 1980 which was increased 1851 sq km during 2009 in the study area. The sea-level rise, increasing salinity and availability of less fresh water are responsible for inland intrusion of saline water and creating favorable environment for shrimp farming in the region. As a result farmers are converting fallow lands to shrimp farming which is economically very beneficial. Important agricultural and non-agricultural lands also converted by homestead intended for increasing population of Bangladesh. There was only 398 sq km (only 5\%) area covered by homestead during 1980. But the homestead covered area was increased about $1490 \mathrm{sq} \mathrm{km} \mathrm{(19 \% )} \mathrm{at} \mathrm{2009.} \mathrm{So,} \mathrm{compared} \mathrm{to} \mathrm{the} \mathrm{last} 30$ years $14 \%$ homesteads land cover areas are increased. There was not any astonishing changed in mangrove vegetation. Some mangroves areas were shattered and some other mangroves were fullfledged again in delta areas. The harmful land cover changes are not expectable for the natural environment. But it transpires by many natural and anthropogenic tricks now a day. So, the authority should seize initiatives to protect this category of catastrophe.
\end{abstract}

\section{INTRODUCTION}

The Sundarban mangrove forest is the largest remaining tract of mangrove forest in the world. It is an independent biome and very rich in biodiversity. Over 1186 numbers of known living species (flora and fauna) are found in the biome [Duke et al. (2008)]. It provides important ecosystem services in the region as well as protects coastal people from many harmful natural disasters. Over one million people directly or indirectly depend on the forest for their livelihood and the forest contributes great amount of Gross Domestic Product (GDP) in Bangladesh [Giri et al. (2008)].

Due to the various man-made and also for some natural reasons different species in the Sundarbans are reducing at a significant level and land cover is changing day to day. Homestead (houses accompanied by evergreen broadleaf type vegetation), agricultural land (standing crop and fallow), water (rivers,

\footnotetext{
${ }^{1}$ Environmental Science Discipline, Khulna University, Bangladesh

${ }^{2}$ Environmental Science Discipline, Khulna University, Bangladesh
} 
ponds, shrimp farms), mangrove vegetation, etc patterns are some of the main changed in the Sundarban mangrove forest area.

Although the Sundarban mangrove ecosystems have tremendous value for south-west coastal communities and associated species, they are being destroyed at alarming rates. Human threats to the mangroves include the overexploitation of forest resources by local communities, conversion into large scale development such as agriculture, forestry, salt extraction, urban development and infrastructure and diversion of freshwater for irrigation. The greatest human threat to the mangroves is the establishment of shrimp aquaculture ponds. Because the mangroves are often viewed as wastelands, many developing countries are replacing these forests with agricultural land or shrimp aquaculture production. Shrimp aquaculture accounts for the loss of 20 to 50 percent of mangrove in the world [UNEP (1994)].

This research focuses only on the spatial and temporal dynamics of land cover and its impact on the ecosystem in Khulna and Satkhira districts in Bangladesh where majority of the Bangladesh's portion of the mangrove forest is located. Moreover, it is extremely difficult to get into vast swamps of the mangrove forests and conducting field inventory is time consuming and costly. The study period was chosen from 1980 to 2009, about 30 years.

\section{STUDY AREA}

Khulna and Satkhira are two of the south western districts of Bangladesh lie between the latitudes from $21^{\circ} 30^{\prime \prime} \mathrm{N}$ to $23^{\circ} 30^{\prime \prime} \mathrm{N}$ and Longitudes from $88^{\circ} 55^{\prime \prime} \mathrm{E}$ to $89^{\circ} 35^{\prime \prime}$ E. They occupy total land area of $7083 \mathrm{sq} \mathrm{km}$ where some small urban areas are present. Out of which $1585 \mathrm{sq} \mathrm{km}$ is mangrove forest which is about $39 \%$ of the entire mangrove forest. Most of the areas are generally fallow land. The main different things of this area from the other parts of the country, is the present of largest mangrove forest the Sundarbans. It is one of the most biodiversities areas of the world. It is one of the most important mangrove areas because many endemic and threatened flora and fauna present here. The study site is also heavily populated agricultural land cover dominated areas at the delta of the Ganges, Brahmaputra and Meghna rivers on the coast of Bay of Bengal [BBS (2001)].

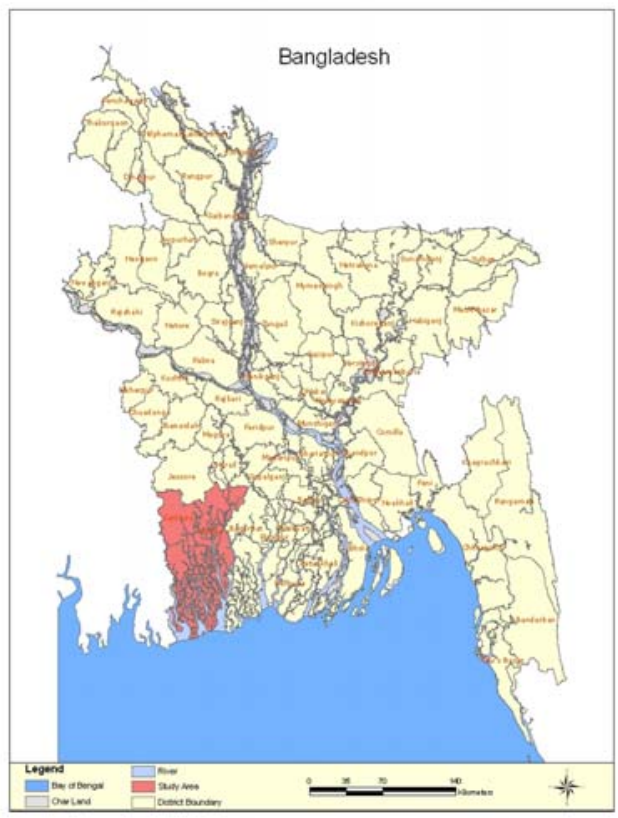

Fig 1: Location map of the study area. 


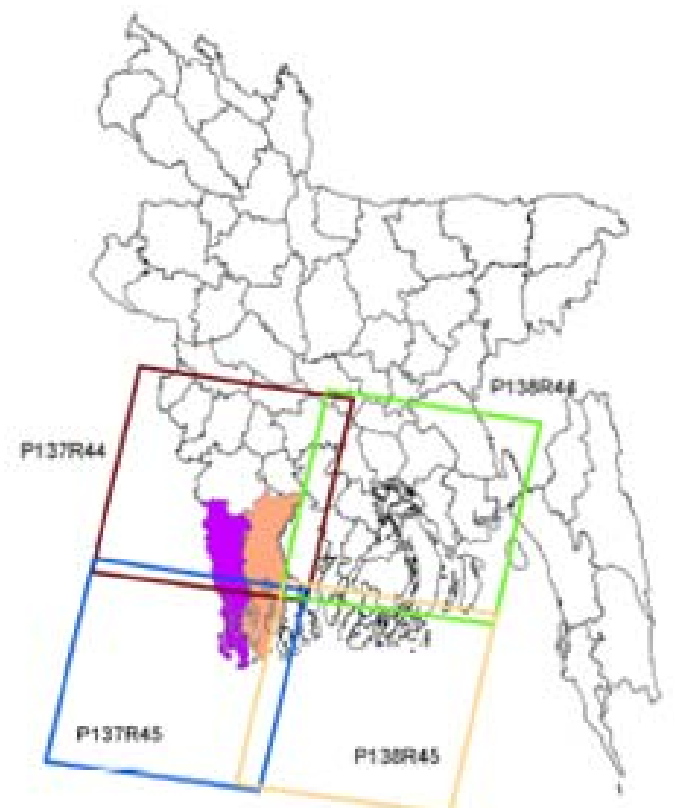

Fig 2: Four scenes of Landsat, p137r44, p137r45, p138r44 and p138r45

The entire area of these two districts lies in four scenes of Landsat, p137r44, p137r45, p138r44 and p138r45. However, areas only covered by p137r44 and p137r45 scenes of Landsat were considered due to lack of accessibility of the data which left around 13\% of the area in Khulna district out of the analysis.

\section{MATERIALS AND METHODS}

\section{Data collection}

The research generally based on secondary data, satellite image and remote sensing and GIS software's. There has been used Landsat images to derived historical land cover maps of 30-year. Landsat image spatial and spectral characteristics were suitable to derive land cover at local scale and provide longest historical records at free of cost. Images acquired in the months of January and February were selected considering vegetation phenology, cropping pattern in the region and less cloudy time periods of the year. Actual study interval period was compromised depending on availability of cloud free quality images. Fig 3 shows the raw images of Landsat satellite images of the 30 years, 1980 to 2009.

Table 1 provides the actual acquisition dates of the images, spatial resolution and associated sensors that were used in the study. Data from three sensors of Landsat, Multi Spectral Scanner (MSS), Thematic Mapper (TM) and Enhanced Thematic Plus (ETM+) were used to derive land cover maps in satellite image. 


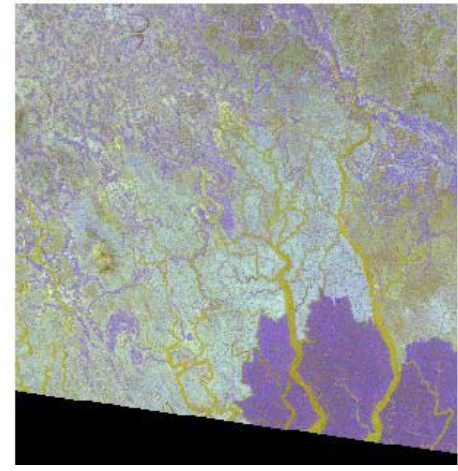

44-1980

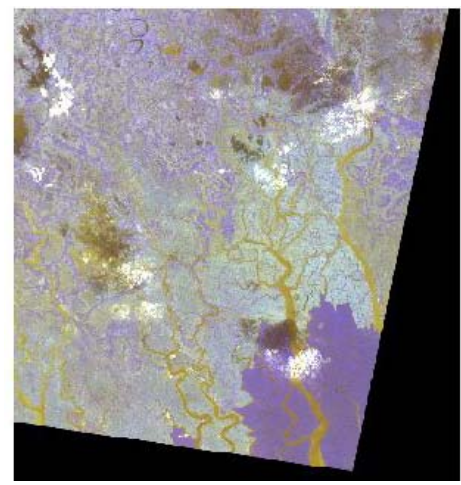

44-1989

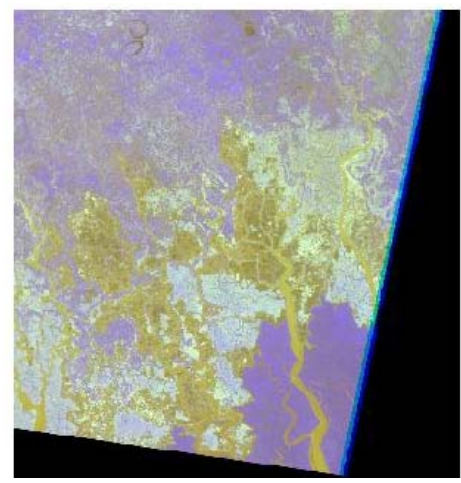

44-2002

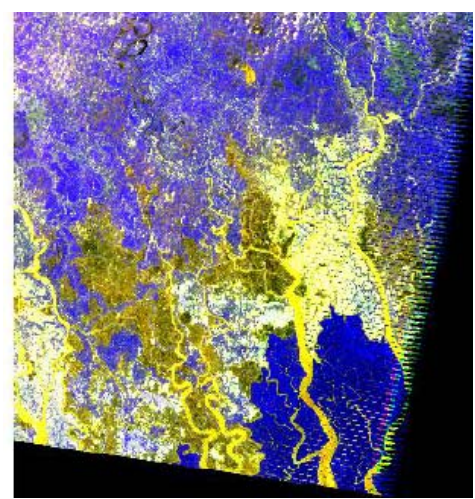

44-2009

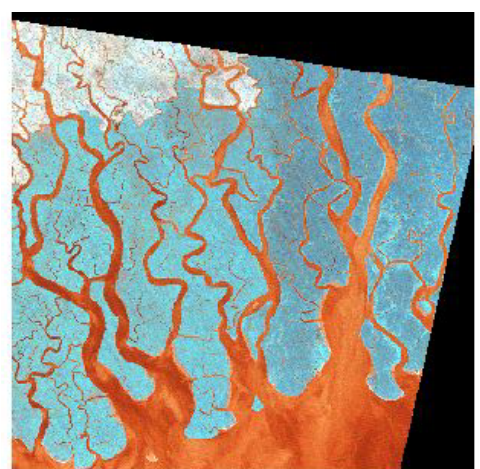

45-1980

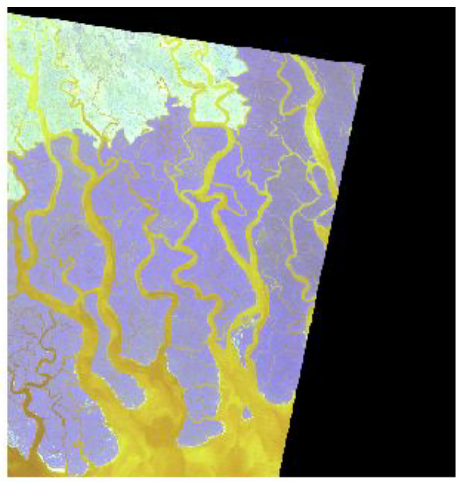

45-1989

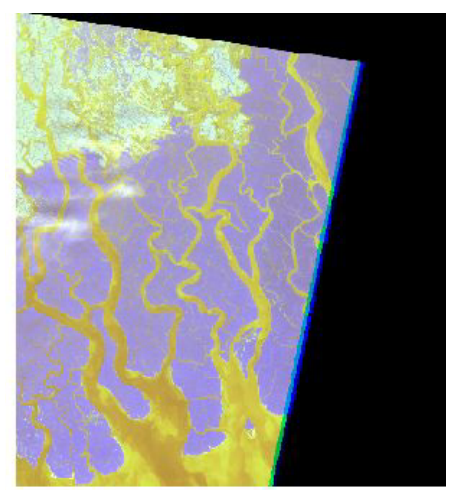

45-2002

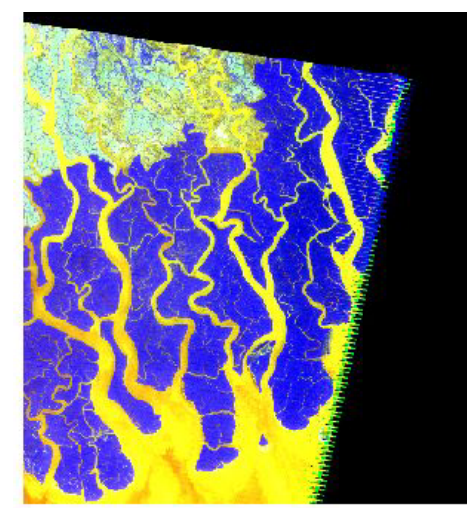

45-2009

Fig 3: Raw images of Landsat satellite from 1980-2009 years 
Table 1: List of image dates and sensors

\begin{tabular}{lllll}
\hline \multirow{2}{*}{ Year } & \multirow{2}{*}{ Sensors } & Spatial resolution $(\mathrm{m})$ & P137R44 & P138R45 \\
\cline { 4 - 5 } & & & Dates & Dates \\
\hline 1980 & MSS & 60 & 16 January & 21 February \\
1989 & TM & 30 & 3 January & 19 January \\
2002 & TM & 30 & 24 February & 8 February \\
2009 & ETM+ & 30 & 24 Feb-primary & 10 Jan-primary \\
& SLC Off & & 28 Mar 08-Filled & 25 Dec 08-filled \\
\hline
\end{tabular}

\section{GIS and remote sensing softwares use}

In this study some modern software and systems were used. The image classification and recoded techniques employed in this study were conducted using Erdas Imagine 8.4 software which is remote sensing software. The next steps, such as convert classified recoded image into grid, joint the grid study areas in same years and at last clipping the study area to get actual results were conducted by Arc view 3.2a with extension of Imagine image support, Spatial Analyst and Image Analyst software.

\section{Data Processing and preparation of maps}

Classification scheme: A five-class Landsat data suitable, site specific, objective oriented classification scheme was developed through careful visual interpretation of all the images. The classes along with their descriptions are provided in Table 2.

Table 2: Land cover classification scheme

\begin{tabular}{|c|c|c|}
\hline Classes & Name & Descriptions \\
\hline 1 & Homestead & $\begin{array}{l}\text { This class includes all the rural houses that are } \\
\text { accompanied by vegetation mostly fruit and wood } \\
\text { trees; evergreen woody vegetation along the roads, } \\
\text { canals, rivers and railways; and small towns and } \\
\text { growth centers }\end{array}$ \\
\hline 2 & Fallow land & $\begin{array}{l}\text { This class includes all types of cultivable lands with } \\
\text { or without any standing crops and also uncultivable } \\
\text { lands which can be cultivated }\end{array}$ \\
\hline 3 & Mangrove vegetation & $\begin{array}{l}\text { This covers the mangrove vegetation only to detect } \\
\text { the Sundarbans forest extent }\end{array}$ \\
\hline 4 & Water bodies & $\begin{array}{l}\text { This class includes all the surface water bodies, e.g, } \\
\text { rivers, canals, ponds, shrimp farms etc. }\end{array}$ \\
\hline 5 & Cloud and shadows & This class includes clouds, associated shadows \\
\hline
\end{tabular}

Image classification: Classification is the process of sorting pixels into a finite number of individual classes or categories of data, based on their data file values. If a pixel satisfies a certain set of criteria, then the pixel is assigned to the class that corresponds to those criteria.

Signature editor files: The ERDAS IMAGINE Signature editor allows to create, manage, evaluate, edit and classify signature. The following types of signatures can be defined. 
Recoding classified image: Recoded are the next steps after image classification. Classified images have converted into recoded image to identify one class by one fixed color. There were five classes are recoded in each image. Then recoding has been done and different land feature classes were assigned after studying the spectral profile.

Converting recoded images into GRID: The Arc view with the help of loading Arc view extensions Imagine image support, Image analyst and Spatial analyst can be converted each recoded image into GRID. So the eight recoded images have converted into GRID.

Joining same years' GRID: After converting classified recoded image into GRID, the same year two GRID image have jointed together to formulate one year's one GRID image to cover total study area.

Converting shape file of study area into GRID: The study area was present as shape file. The shape file of study area has converted same way into GRID.

Clipping the study area from the joint GRID: After joining two GRID of same year, the GRID study area has loaded upon the Joint GRID classified image and then clipped the actual classified GRID study area. In this way, there were four years classified GRID study areas' maps have been gotten.

Calculation of different land covers areas: From the each year's classified GRID maps, the different land covers areas have been calculated. Then it has compared the five classified fields with each others for the research results preparation.

GPS based ground survey: In this step, areas belonging to different class categories have been selected from the classified image and have been taken as a basis for field investigation. A global positioning system (GPS) has been used to locate each of these selected areas with a good precision. Then detailed observations on the locations have been made over each of these selected areas. The information on homestead, fallow lands, water bodies and mangroves have also been collected from some selected areas. Such a step based on a limited number of ground observations provided an interpretation key to classify the study.

\section{RESULTS AND DISCUSSIONS}

Types of land cover changes: Land use pattern of the study area in 1980, 1989, 2002 and 2009 as interpreted from different satellite images are presented as Maps in 1, 2, 3 and 4 respectively and Table 3. There were mainly four kinds of changes find out in the research by analysis 30 years satellite data images which have been processed by various GIS and remote sensing softwares. The main classes of changes were homestead, fallow land, water bodies and mangrove vegetation.

Here homestead means rural houses that were accompanied by vegetation mostly fruit and wood trees; evergreen woody vegetation along the roads, canals, rivers and railways and small towns and growth centers. Fallow land included all types of cultivable lands with or without any standing crops and also uncultivable lands. Water bodies were all types of surface water bodies, such as rivers, canals, ponds, shrimp farms etc. Mangrove vegetation covered the mangrove vegetation only to detect the Sundarbans forest extent. Without these, there were some clouds in three years images (1989, 2002 and 2009). So, the actual data were not found for cloud and cloud shade covered areas.

There was a satellite image data error present in the image of 2002 year. In the east side of that image had about 350 sq km area which could not give actual data for satellite image error. So, it could not be identified the information of that error areas. 
There were also present some zero value in the three years images because the lack of image availability and expensiveness. The zero value means the valueless areas or no data areas in the study area.

After the image analysis, classifying and the processing, it has been identified the types of changes in the last 30 years. The homestead areas had increased and fallow lands had decreased a large quantity. The water bodies (shrimp farming) had distinctly increased in the last 30 years. There was not any remarkable changed in mangrove vegetation. Some mangroves areas were destroyed and some other mangroves were grown up again in delta areas.

The types of changes can be easily identified by the observation of classified image maps of study areas' in 1980, 1989, 2002 and 2009 years respectively. In the Map 1 (1980) the homestead areas were remarkable less and fallow lands were a vast amount, about half of total study area. Water bodies were also very less than comparatively other years' maps. It was increasing day by day. In the Map 4 (2009) the water bodies were significantly increase and fallow lands were decreased than Map 1 (1980). In the Map 3, 1989 year's had many cloud covered areas than other years' maps.

Mangroves were decreased slowly from 1980 to 2002. But in 2009, it is found that mangroves were again increased. The estuarine new born islands, deltas were responsible for mangroves increased.

So above discussion from maps, it has cleared that homestead were increased, fallow lands were decreased and water bodies were increased by shrimp farming continuously in last 30 years.

Table 3: Land use coverage identified by Landsat data of the study area

\begin{tabular}{|l|l|l|l|l|l|l|l|}
\hline Year & $\begin{array}{l}\text { Home stead } \\
(\mathrm{sqkm})\end{array}$ & $\begin{array}{l}\text { Fallow lands } \\
(\mathrm{sqkm})\end{array}$ & $\begin{array}{l}\text { Water Bodies } \\
(\mathrm{sqkm})\end{array}$ & $\begin{array}{l}\text { Mangrove } \\
(\mathrm{sqkm})\end{array}$ & $\begin{array}{l}\text { Cloud } \\
(\mathrm{sqkm})\end{array}$ & $\begin{array}{l}0 \text { value } \\
(\mathrm{sqkm})\end{array}$ & $\begin{array}{l}\text { error } \\
(\mathrm{sqkm})\end{array}$ \\
\hline 1980 & 398 & 3867 & 1140 & 2469 & 0 & 0 & 0 \\
\hline 1989 & 683 & 3068 & 1265 & 2269 & 356 & 231 & 0 \\
\hline 2002 & 1061 & 2451 & 1799 & 2058 & 27 & 127 & 350 \\
\hline 2009 & 1490 & 2259 & 1851 & 2244 & 11 & 20 & 0 \\
\hline
\end{tabular}

Table 4: Land use pattern and its change in Khulna and Satkhira region, 1980-2009

\begin{tabular}{|c|c|c|c|c|c|c|c|c|c|c|c|}
\hline $\begin{array}{l}\text { Land use } \\
\text { category }\end{array}$ & $\begin{array}{l}\text { Area in } \\
(\mathrm{sqkm}) \\
\text { at } 1980\end{array}$ & $\begin{array}{ll}\begin{array}{l}\text { Area } \\
\%\end{array} & \text { in } \\
1980 & \text { at } \\
\end{array}$ & $\begin{array}{ll}\begin{array}{l}\text { Area in } \\
(\mathrm{sqkm})\end{array} & \text { at } \\
1989 & \end{array}$ & $\begin{array}{l}\text { Area in \% } \\
\text { at } 1989\end{array}$ & $\begin{array}{l}\text { Change \% } \\
(1980- \\
1989)\end{array}$ & $\begin{array}{ll}\begin{array}{l}\text { Area } \\
(\mathrm{sqkm})\end{array} & \text { at } \\
2002 & \end{array}$ & $\begin{array}{ll}\text { Area } & \text { in } \\
\% & \text { at } \\
2002 & \end{array}$ & $\begin{array}{l}\text { Change \% } \\
\text { (1989- } \\
2002)\end{array}$ & $\begin{array}{l}\text { Area in } \\
(\mathrm{sqkm}) \\
\text { at } 2009\end{array}$ & $\begin{array}{l}\text { Area in } \\
\% \quad \text { at } \\
2009\end{array}$ & $\begin{array}{l}\text { Change } \\
\% \\
(2002- \\
2009)\end{array}$ \\
\hline $\begin{array}{l}\text { Home } \\
\text { stead }\end{array}$ & 398 & 5 & 683 & 9 & +4 & 1061 & 13 & +4 & 1490 & 19 & +6 \\
\hline $\begin{array}{l}\text { Fallow } \\
\text { lands }\end{array}$ & 3867 & 49 & 3068 & 39 & -10 & 2451 & 31 & -8 & 2259 & 29 & -2 \\
\hline $\begin{array}{l}\text { Water } \\
\text { Bodies }\end{array}$ & 1140 & 14 & 1265 & 16 & +2 & 1799 & 23 & +7 & 1851 & 24 & +1 \\
\hline $\begin{array}{l}\text { Man- } \\
\text { grove }\end{array}$ & 2469 & 31 & 2269 & 29 & -2 & 2058 & 26 & -3 & 2244 & 29 & +3 \\
\hline Cloud & 0 & 0 & 356 & 5 & +5 & 27 & 0.34 & -4.66 & 11 & 0.14 & -0.20 \\
\hline
\end{tabular}




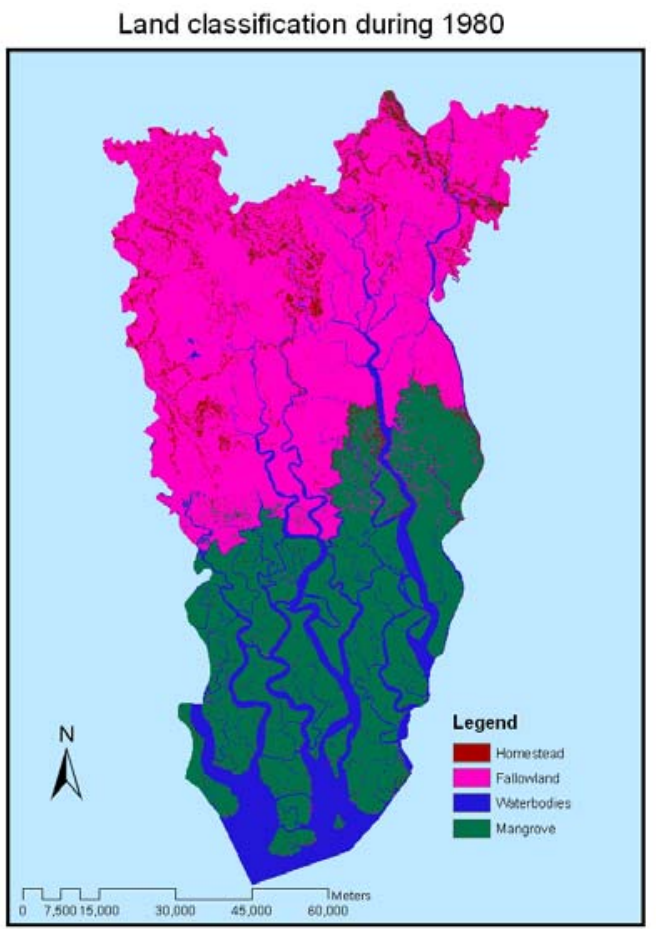

Map 1: Land classification of Landsat image during 1980 in the study area

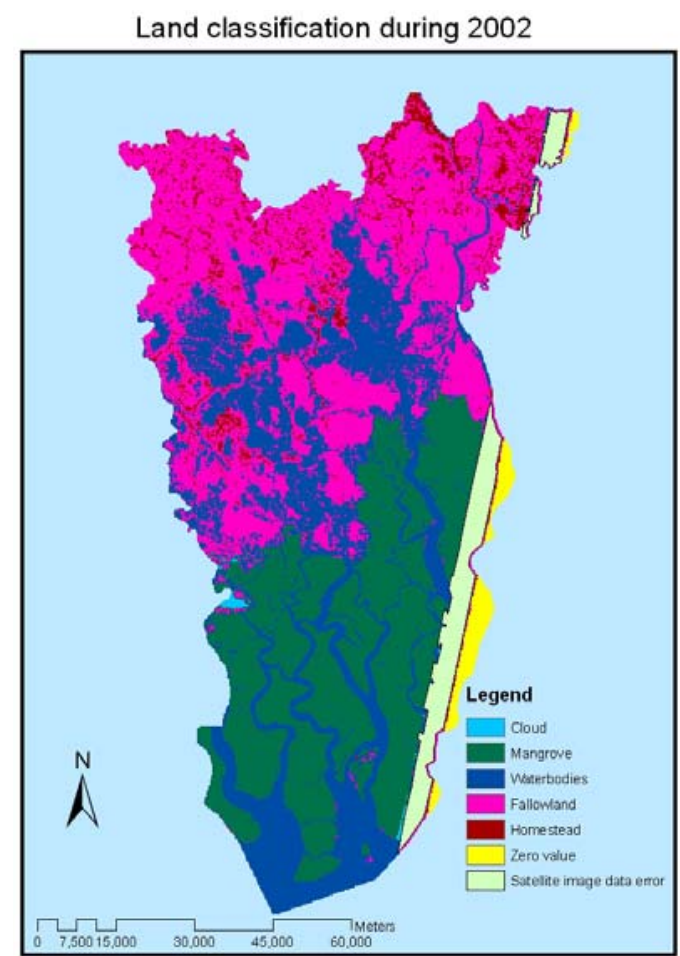

Map 3: Land classification of Landsat image during 2002 in the study area

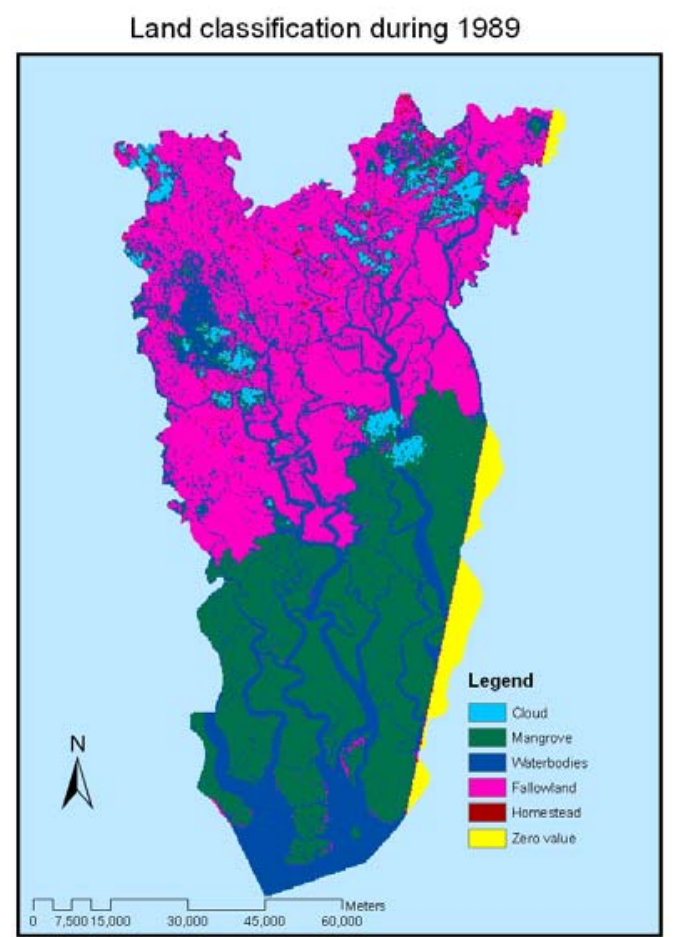

Map 2: Land classification of Landsat image during 1989 in the study area

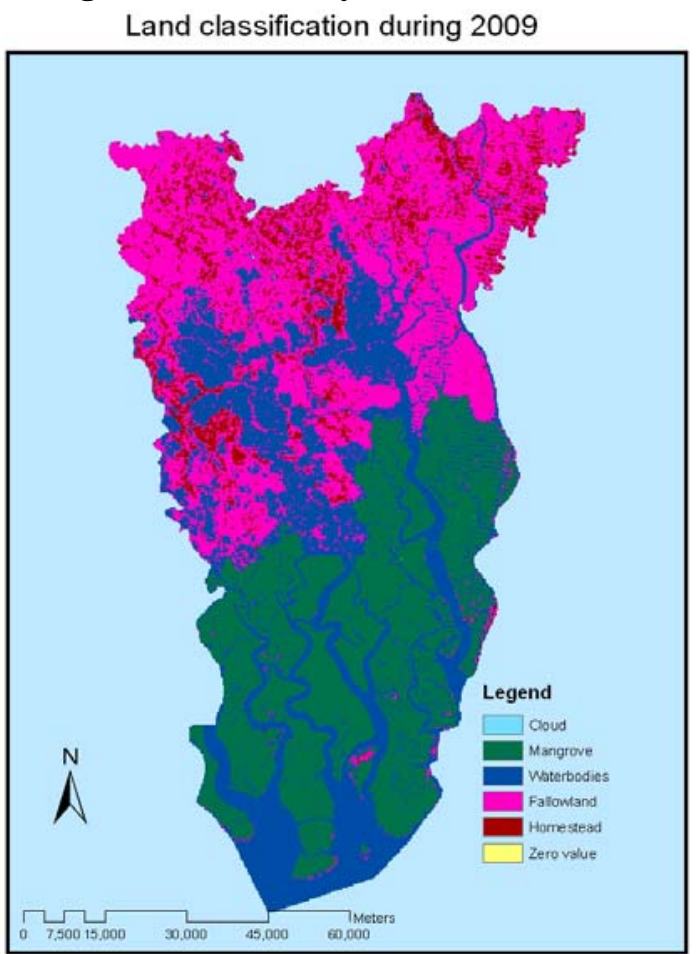

Map 4: Land classification of Landsat image during 2009 in the study area

\section{Fallow lands}

The most important change was observed in fallow lands. Previously it has been said that fallow lands are all types of cultivable lands with or without any standing crops and also uncultivable lands which 
can be cultivated. Total amount of fallow in 2009 was 2,259 sq km which decreased a vast amount from previous years. During 1980, total fallow land was 3,867 sq km. It was dropped during 1989, about 3,068 sq km and dropped again for the duration of 2002, 2,451 sq km (Fig 4). So that, according to observation of last 30 years results, it is clear that fallow land is decreasing day by day.

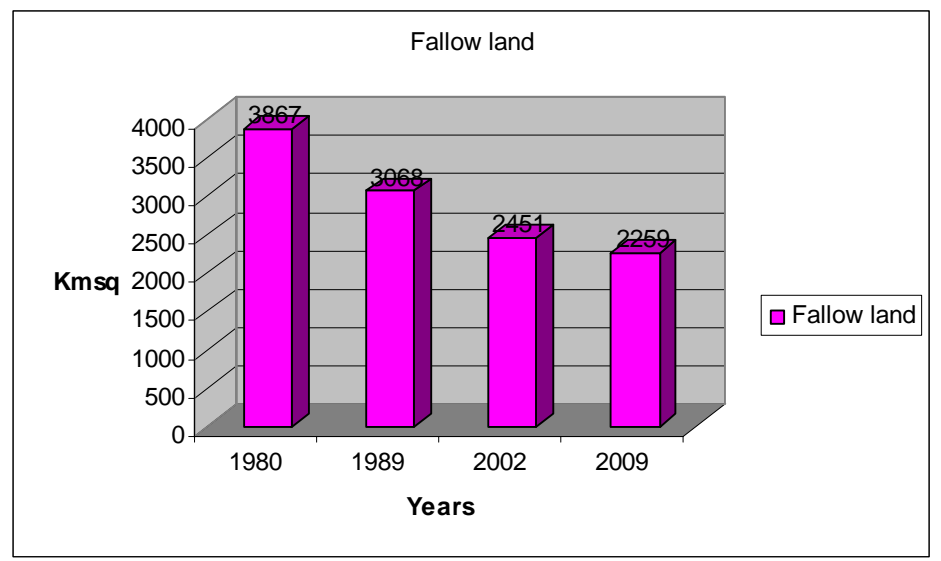

Fig 4: Fallow lands covered areas from 1980 to 2009 in Khulna and Satkhira districts

\section{Water bodies}

So the next important change was observed in water bodies. The water bodies were increased about $10 \%$ in the last 30 years. It was 14\%, 16\%, 23\% and 24\% of total area during 1980, 1989, 2002 and 2009 years respectively. The total water bodies covered $1140 \mathrm{sq} \mathrm{km}$ at 1980 which also covered 1265 sq km, 1799 sq km and 1851 sq km at the period of 1989, 2002 and 2009 respectively (Fig 5).

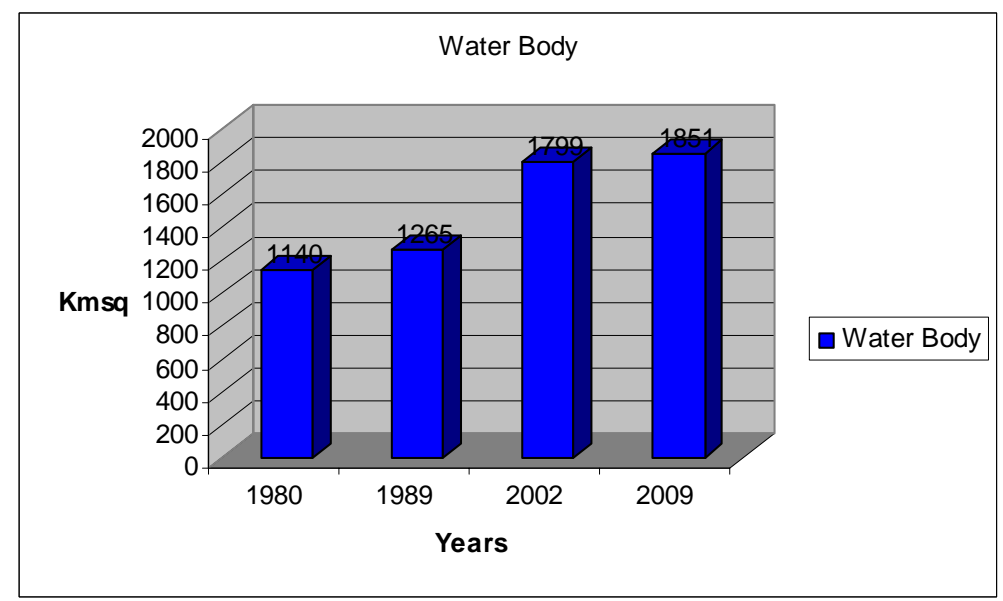

Fig 5: Water bodies covered areas from 1980 to 2009 in Khulna and Satkhira districts

\section{Homestead}

Another most important change of land cover is increasing homestead by dropping fallow lands. Population of Bangladesh is increasing logistically day by day. So important agricultural and nonagricultural lands converted by homestead. There was only $398 \mathrm{sq} \mathrm{km}$ area covered by homestead during 1980. But the homestead covered area was increased about $1490 \mathrm{sq} \mathrm{km}$ at 2009. It was covered 683 sq km and 1061 sq km during 1989 and 2002 respectively (Fig 6). 


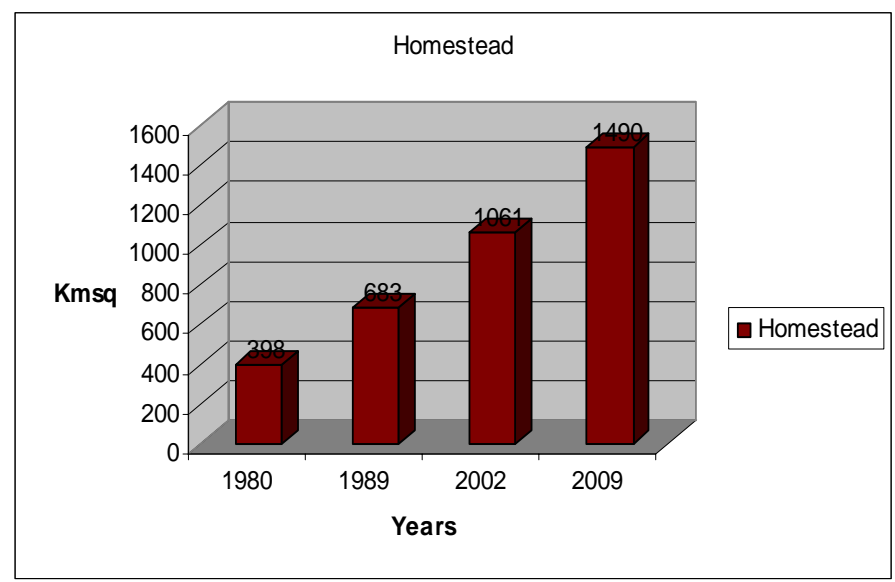

Fig 6: Homestead covered areas from 1980 to 2009 in Khulna and Satkhira districts

\section{Mangrove}

The mangrove forest area remained much constant through out the study period of the area both in Satkhira and Khulna districts. Mangrove covered $2469 \mathrm{sq} \mathrm{km}$ in the time of 1980. It quite dropped during 1989, covered 2269 sq km. Mangrove again dropped, about 2058 sq km at the period of 2002. But the examination of 2009 maps (Map 4), it indicate Mangrove covered $2244 \mathrm{sq} \mathrm{km}$ area. Mangrove is increasing from 2002 to 2009. There are many deltas form on the mouth of the estuarine river which responsible to build up new mangrove area. Though, there are many mangroves destroy by natural and anthropogenic activities but new build up mangroves in delta regions responsible to remain constant of it (Fig 7).

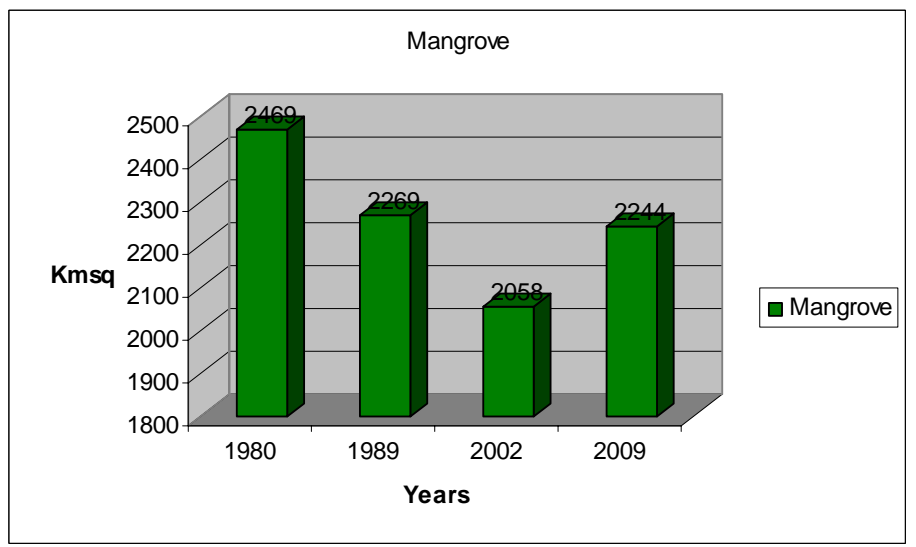

Fig 7: Mangrove covered areas from 1980 to 2009 in Khulna and Satkhira districts

\section{Clouds}

There are no clouds in the 1980 image. But clouds present in the other three images, 1989, 2002 and 2009. The actual data and information about land cover can not be understood in the cloud cover areas in the satellite image map. There was $356 \mathrm{sq} \mathrm{km}$ area covered by cloud, as regards $5 \%$ of total area at the period of 1989 . Cloud covered area was $27 \mathrm{sq} \mathrm{km}$, about $0.34 \%$ area in $2002.11 \mathrm{sqkm}$ area covered by cloud during 2009, which was very less quantity, about $0.139 \%$ of total study area (Fig 8). 


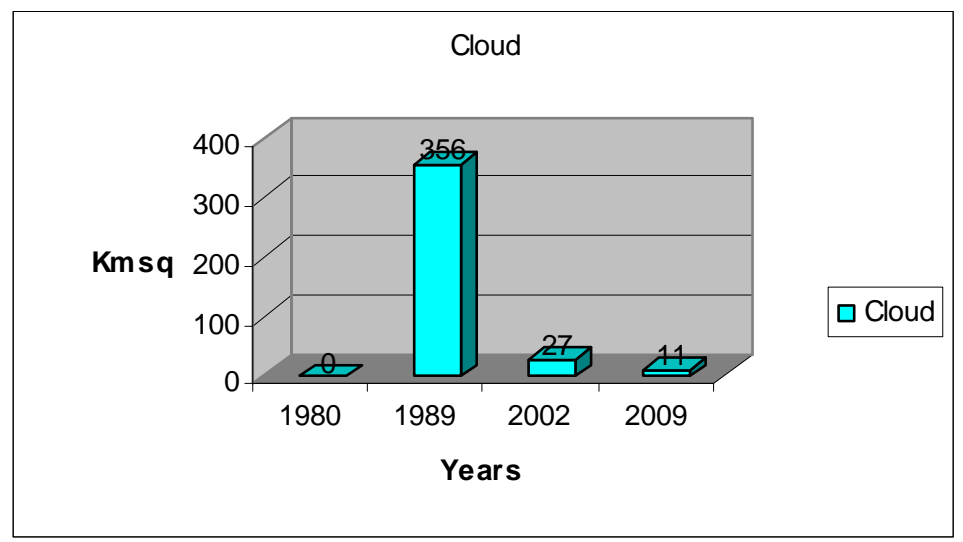

Fig 8: Cloud covered areas from 1980 to 2009 Landsat images in Khulna and Satkhira districts

\section{The Main Causes of the Land Cover Changes}

After reviewing many these research related literature and doing research works, some concept about land cover changing has been gained by researcher. It has been found that there are main two reasons to responsible of land cover changes. Those are

- Natural causes and

- Anthropogenic causes.

\section{Natural causes}

There are many natural causes accountable to land cover changes. The most common natural causes are following:

- Global warming

- Climate change

- Sea Level Rise (SLR)

- Cyclone

- Storm surges

- Coastal flood

- Salinity intrusions

- Water logging

- Coastal erosion etc.

\section{Anthropogenic causes}

There are also many anthropogenic causes responsible to land cover changes. The most common anthropogenic causes are following:

- Population growth

- Unplanned shrimp cultivations

- Salinity intrusions

- Water logging

- Increase economical activities

- Timber and raw materials collect from Sundarbans

- Fisheries 
- Gander issue

- Political unrest

- Illiteracy of local people about harmful effect of land cover changes

- Poverty

- Tendency to earn more money etc.

\section{CONCLUSION}

The land covers in the region are changing, the most noticeable change was conversion of fallow (agricultural or non-agricultural) land to shrimp farming and homestead between 1989 and 2002. The salinity intrusions in the region aided the growth in shrimp farming following a low to high gradient from east to west. Loss of agricultural land and increased water areas have amplified the salinity imbalance in the region through reduced surface runoff and loss of vegetation coverage, leading to decrease in ecosystem productivity following the same low to high gradient from east to west in the study areas.

The homestead areas had increased and fallow lands had decreased a large quantity. The water bodies had noticeably increased in the last 30 years. There was not any remarkable changed in mangrove vegetation. Some mangroves areas were destroyed and some other mangroves were grown up again in delta areas. The estuarine new born islands, deltas were responsible for mangroves increased. So above discussion and the previous maps, it has cleared and reached the decision of that the homestead were increased, fallow lands were decreased and water bodies were increased by many ways continuously in last 30 years. The study was conducted on a very small part of the country and differences in the characteristics of data are substantial considering rapidly developing satellite technology. So, it is difficult to reach a decisive conclusion based on such materials along.

Acknowledgement: Special thanks and acknowledge to Shahriar Pervez, Senior Scientist of SGT Inc, Contractor to United States' Geological Survey (USGS) of Earth Resources and Science Center (EROS) who gave the Landsat satellite images of 30 years from NASA. The researchers are also grateful to Md. Zillur Rahman, Senior GIS specialist of NRICA International Ltd. who gave all softwares, data, suggestions and supports to be accomplished the research work.

$\begin{array}{ll}\text { Abbreviations } & \\ \text { BBS } & \text { Bangladesh Bureau of Statistics } \\ \text { EROS } & \text { Earth Resources and Science Center } \\ \text { ETM+ } & \text { Enhanced Thematic Plus } \\ \text { MSS } & \text { Multi Spectral Scanner } \\ \text { NASA } & \text { National Atmospheric and Space Administration } \\ \text { TM } & \text { Thematic Mapper } \\ \text { UNEP } & \text { United Nations Environmental Programme } \\ \text { USGS } & \text { United States' Geological Survey }\end{array}$




\section{REFERENCES}

Giri, C., Zhu, Z., Tieszen, L. L., Singh, A., Gillette, S., and Kelmelis, J. A. (2008) Mangrove forest distributions and dynamics (1975-2005) of the tsunami-affected region of Asia. Journal of Biogeography, 35(3), pp. 519-528

Gerard, B. Richard, E., Delphine, F. and Anne-Thérèse, H. N. (2005) Remote sensing: a tool to monitor and assess desertification. Les dossiers thématiques du CSFD .

Burrough, P. (2001) Priciple of Geographic Information System for Land Resource Assessment. Clarendon, Chapman and Hall.

Gilman, E.L., Ellison, J., Duke, N.C., and Field, C. (2008) Threats to mangroves from climate change and adaptation options: A review. Aquatic Botany, 89, pp. 237-250

Giri, C., Zhu, Z., Tieszen, L. L., Singh, A., Gillette, S., and Kelmelis, J. A. (2008) Mangrove forest distributions and dynamics (1975-2005) of the tsunami-affected region of Asia. Journal of Biogeography, 35(3), pp. 519-528

Konecny, G. (2003) Geoinformation: Remotr sensing, Photogrammetry and Geographic Information System. London and New York, Taylor and Francis. 